\title{
Feminists Read Habermas \\ - den amerikanske feministiske Habermas-kritik stiller nye teoretiske spørgsmål
}

Af Christina FiIg

Artiklen presenterer den amerikanske feministiske Habermaskritik og giver en lesning af roungs anerkendelsesbegreb. roung udfolder ber to dimensioner; politisk-økonomisk og kulturel anerkendelse. Begrebet anvendes til at diskutere kvinder, kvindebevagelse og feminisme i Habermas' demokratiteori. Forfatteren argumentever for, at Youngs dobbeltperspektiv er frugtbart baide hos Habermas og $i$ nordisk forskning om kvinder $i$ politik.

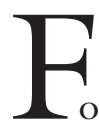

ormålet med denne artikel er at præsentere nogle af de spørgsmål, som feministiske politologer, sociologer og filosoffer siden slutningen af 1980'erne har stillet til Jürgen Habermas. Idealerne om inklusion og deltagelse udgør to af de bærende normative idéer i Habermas' demokratimodel; det diskursteoretiske demokrati, som det er formuleret i hans 1990'er hovedværk Fakticität und Geltung. Disse idealer indgår som vigtige omdrejningspunkter i den amerikanske, feministiske Habermas-kritik. Den amerikanske filosof Iris Marion Youngs anerkendelsesbegreb med både en politisk-økonomisk og en kulturel dimension anvendes i Habermas' model til at diskutere kvinder, kvindebevægelse og feminisme og anerkendelse heraf. Det er Youngs pointe, at kvinder er ekskluderede af politik. Hendes anerkendelsesbegreb giver et teoretisk grundlag at diskutere eksklusion på baggrund af og desuden en mulighed for at kombinere et eksklusions- og et inklusionsperspektiv på kvinders politiske 
deltagelse. Dette er frugtbart i relation til Habermas' demokratimodel og til nordisk forskning om kvinder i politik.

\section{INTRODUKTION}

What about wife-beating, Mr. Habermas?, lød det fra plenum, da den tyske sociolog og historiker gæsteforlæste på Aarhus Universitet i midten af 1980'erne.

Spørgsmålet var rettet mod den kønsblindhed, som dominerede habermasiansk teori. Svaret fortaber sig i det fjerne, men ville givetvis afspejle, at kønsdimensionen ikke indgik i Habermas' 1980'er-værk: Theorie des kommunikativen Handels og den heraf udsprungne koloniseringstese. ${ }^{1}$ Med denne teses teoretisering af forholdet mellem offentlige og private institutioner $\mathrm{i}$ klassisk kapitalisme undlader Habermas en kønskontekst, som ville gøre hans analyse bedre (Cohen 1995, Fraser 1995, Habermas 1984, kap.8). Værket rummer derimod en diskussioner af sociale bevægelser. På linje med disse er kvindebevægelsen tildelt en defensiv rolle med det formål at beskytte livsverdenen fra systemets kolonisering. Fra et feministisk perspektiv kan teorien derfor kritiseres for ikke at se det emancipatoriske potentiale i kvindebevægelsen.

1990'ernes Habermas-teori er anderledes, idet vægten er flyttet mod en diskussion af demokrati og dets rolle. I de ti år, der er gået mellem de to værkers udgivelse, er der desuden opstået en skole af feministisk Habermas-kritik. Habermas går i dialog med sin amerikanske feministiske kritik i sit seneste hovedværk Fakticität und Geltung fra 1992.

Formålet med denne artikel er at præsentere et udsnit af denne feministiske tradition og at diskutere nogle af de spørgsmål, som feministiske politologer, sociologer og filosoffer stiller til Habermas. Jeg vil i det følgende diskutere den amerikanske filosof Iris Marion Youngs og hendes to begreber retfærdighed (enabling justice) og anerkendelse (recognition), hvorledes de indgår i
Habermas' (demokrati)teori og afslutningsvist anvende Young som inspiration for nordisk forskning om kvinder i politik. Med en sådan optik åbner jeg for Pandoras xske med spørgsmål. Fra et nordisk kvindekønsforskningsmæssigt ståsted giver den amerikanske Habermas-kritik grund til nysgerrig undren. Den anskuer eksklusionsproblematikken som et centralt fikspunkt i debatten om kvinders deltagelse i politik, hvilket står i modsætning til den nordiske forsknings vægt på kvinders politiske inklusion. Eftersom den amerikanske tradition er ganske forskellig fra nordisk forskning, har jeg valgt at diskutere den del af Habermaskritikken, som er rettet mod de normative forestillinger i hans demokratiteori.

\section{DEN AMERIKANSKE FEMINISTISKE HABERMAS-KRITIK I 1990'ERNE}

De feministiske kritikker udgør ikke en consensus omnium, men dækker en række videnskabelige positioner, som afspejler kompleksiteten i det habermasianske teoriunivers. Den er opstået i USA i slutningen af 1980'erne og har derfor et særligt amerikansk afsæt. En af kritikkens ledende figurer er Seyla Benhabib, som har læst under Habermas i Frankfurt og har udviklet kritikken i USA (Benhabib 1986, 1992, 1996). Kritikken har flere omdrejningspunkter, som er rettet mod koloniseringstesen eller den habermasianske demokratiteori.

For det første er der diskussionen af grænsedragningen mellem den offentlige og den private sfære, som er en klassisk diskussion inden for feministisk politologi og sociologi (Flemming 1995, Fraser 1986, Landes 1988). 2 En anden diskussion omhandler Habermas' diskursetik og dens sondring mellem etiske, moralske og pragmatiske diskurser (Benhabib 1996). En tredje fokuserer på konstruktionen af identitet og forskelle, som af feministiske teoretikere kritiseres for at være styret af idealer om enshed og universalisme (Benhabib og Cornell 1986). 
Den feministiske kritiks første antologi Feminists Read Habermas, som opsamler nogle af de bidrag, der har formet kritikken af Habermas siden 1980'erne, indledes med det provokerende spørgsmål, hvorfor feminister overhovedet har en interesse $i$ at læse Habermas? Hans teoriunivers indskriver sig i oplysningsfilosofiens tradition med vægt på rationalitet og universalisme; to begreber, som mange feministiske teoretikere forkaster. Svaret i bogen er, at teorien anskuet $\mathrm{i}$ et feministisk perspektiv er problematisk, men at den trods dette udgør en ramme for analyser af moralske og sociale normer og det moderne samfunds politik (Meeham (red.) 1995). Et fællestræk for både Habermas og hans feministiske kritikere er deres videnskabsteoretiske afsæt i Frankfurterskolen og kritisk teori. ${ }^{3}$ Habermas tilhører kritisk teoris anden generation, idet han stiller sig kritisk over for Kants bevidsthedsfilosofi og dets monologiske subjekt-objekt-model (Nørager 1985). Den feministiske kritik lægger sig ligeledes i halen på Habermas i kritikken af den kantianske filosofi. Desuden anlægger den et kønsperspektiv på spørgsmålet om dominans, undertrykkelse og emancipation og tager hermed fat i en debat, som ikke tidligere har haft en central plads i traditionen. Dette afspejler en problemorienteret, emancipatorisk tradition i kvinde-kønsforskningen og desuden et eksklusionsperspektiv på kvinders politiske deltagelse (Benhabib 1986, 1992, Fraser 1989).

Forskellen mellem den amerikanske feministiske Habermas-kritik og et nordiske perspektiv på kvinder i politik giver grund til refleksion over den nationale, politiske kontekst og videnskabelige tradition, som disse perspektiver er opstået inden for. I disse år kører en inspirerende debat om køn og medborgerskab, som belyser, hvorledes medborgerskabsbegrebet er omgivet af forskellige diskurser afhængigt af den historiske baggrund, samfundsforståelser og konkrete analyser af kønsdimensioner i medborgerskab (Bussemaker og Voet (red.)
1998). På linje med medborgerskabsbegrebet er analyser af den habermasianske demokratimodel afhængig af den omgivende socio-politiske kontekst. Eksklusionsperspektivet på spørgsmålet om kvinder i politik kan derfor regnes for et særligt amerikansk perspektiv, som ikke afspejler den dominerende tænkning i nordisk forskning på området. I løbet af de sidste 25 år har skandinaviske kvinder opnået en "kritisk masse" på mellem 30-40\% i de nationale forsamlinger, en historisk høj politisk repræsentation og politisk deltagelse for kvinder (Dahlerup 1988). I forlængelse af dette er teorier om kvinder i politik i Norden i vidt omfang baseret på et inklusionsperspektiv. 4

En vigtig niveaumæssig afklaring skal fastlægges i forbindelse med læsning af Habermas og forskellige typer af feministiske kritikker. På den ene side er denne normativ og rettet mod de bærende idealer i Habermas' demokratimodel om deliberation, inklusion, lighed og den kommunikative rationalitet (Benhabib 1992, Young 1996). På den anden side består den også af en empirisk funderet, institutionel kritik, hvis mål er at kombinere normative idealer med en empirisk-sociologisk virkelighed, som afspejler moderne komplekse samfund. Her er fokus rettet mod en kritik af institutioner som velfærdsstaten og offentligheden (Fraser 1992, Landes 1988). Hvis den feministiske Habermas-debat skal have gennemslagskraft og akkuratesse, er det centralt at sondre mellem den teoretiske kritik og kritikken af de empiriske argumenter. Forskellen mellem de to analyseniveauer kan illustreres af de to forskellige offentlighedsmodeller hos Habermas.

Den borgerlige offentlighed, som den er formuleret $\mathrm{i}$ bogen af samme navn, udgør et normativt ideal uden empirisk forankring. Dette illustreres af en historiske analyse af den politiske debat i USA i kolonitiden, som tidsmæssigt er analogt med oplysningstidens offentlige liv, som er Habermas' afsæt (Habermas 1974). Her er der ikke meget, som tyder på, at den rationelle-kritiske di- 
Fra filmen "Thelma and Lonise". Gengivet med venlig tilladelse af United Pictures.

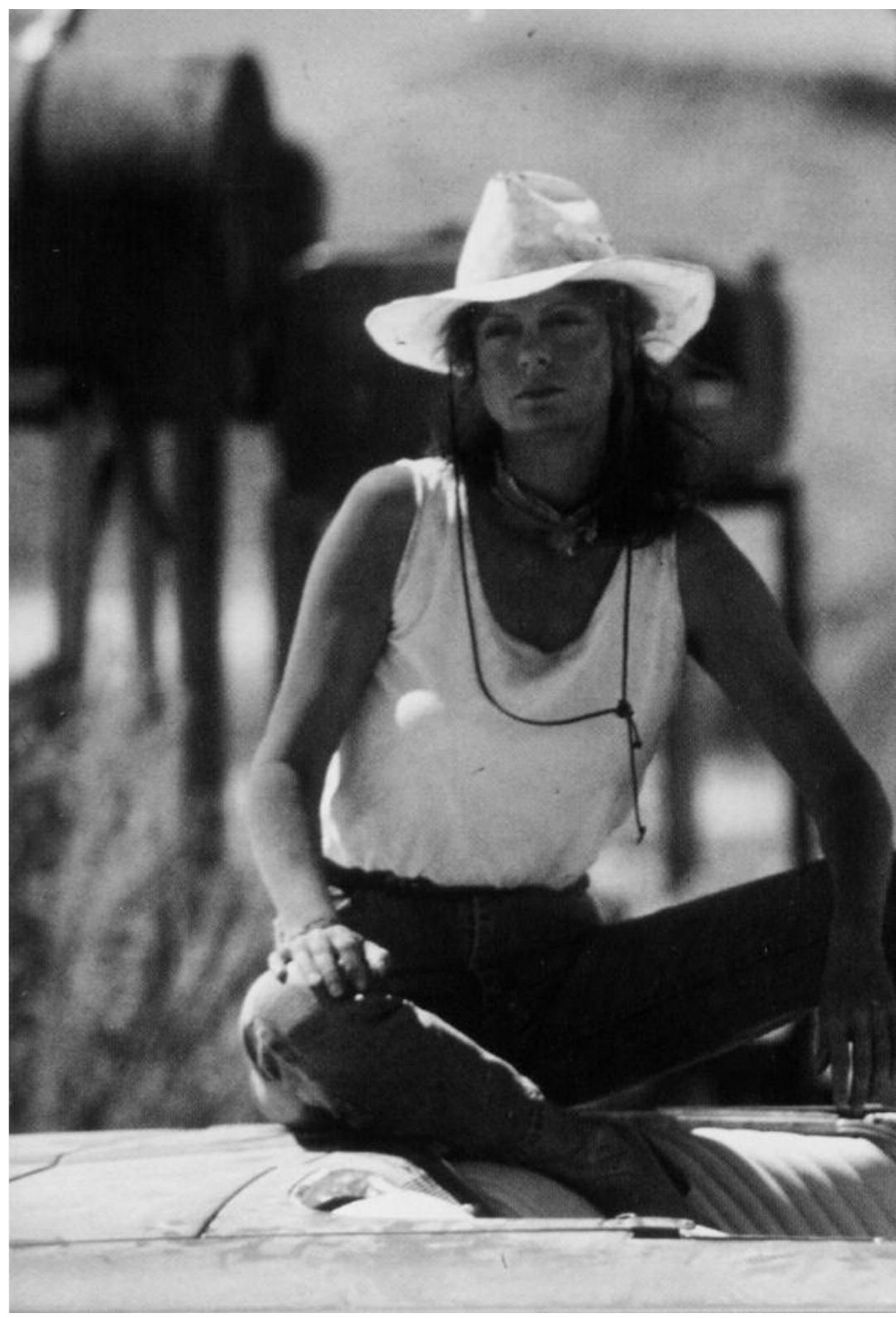

skussion, som Habermas trækker frem for epoken som ideal for den borgerlige offentlighed, reelt var gyldig i amerikansk politik (Scudson 1992). Østerud konkluderer, at som normativ idé og korrektiv til konkrete offentlighedsformer er Habermas' begreb om den borgerlige offentlighed af stor værdi, men at begrebet ikke er i stand til at yde fuld retfærdighed til den specifikke histori- ske ramme omkring den enkelte offentlighedsform (Østerud 1996). 5

I Fakticität und Geltung har offentlighedsmodellen derimod flere dimensioner, idet den både er baseret på en række normative idealer og desuden rummer et empirisk orienteret pluralistisk offentlighedsbegreb med del-offentligheder i civilsamfundet. Habermas har selv anvendt denne op- 


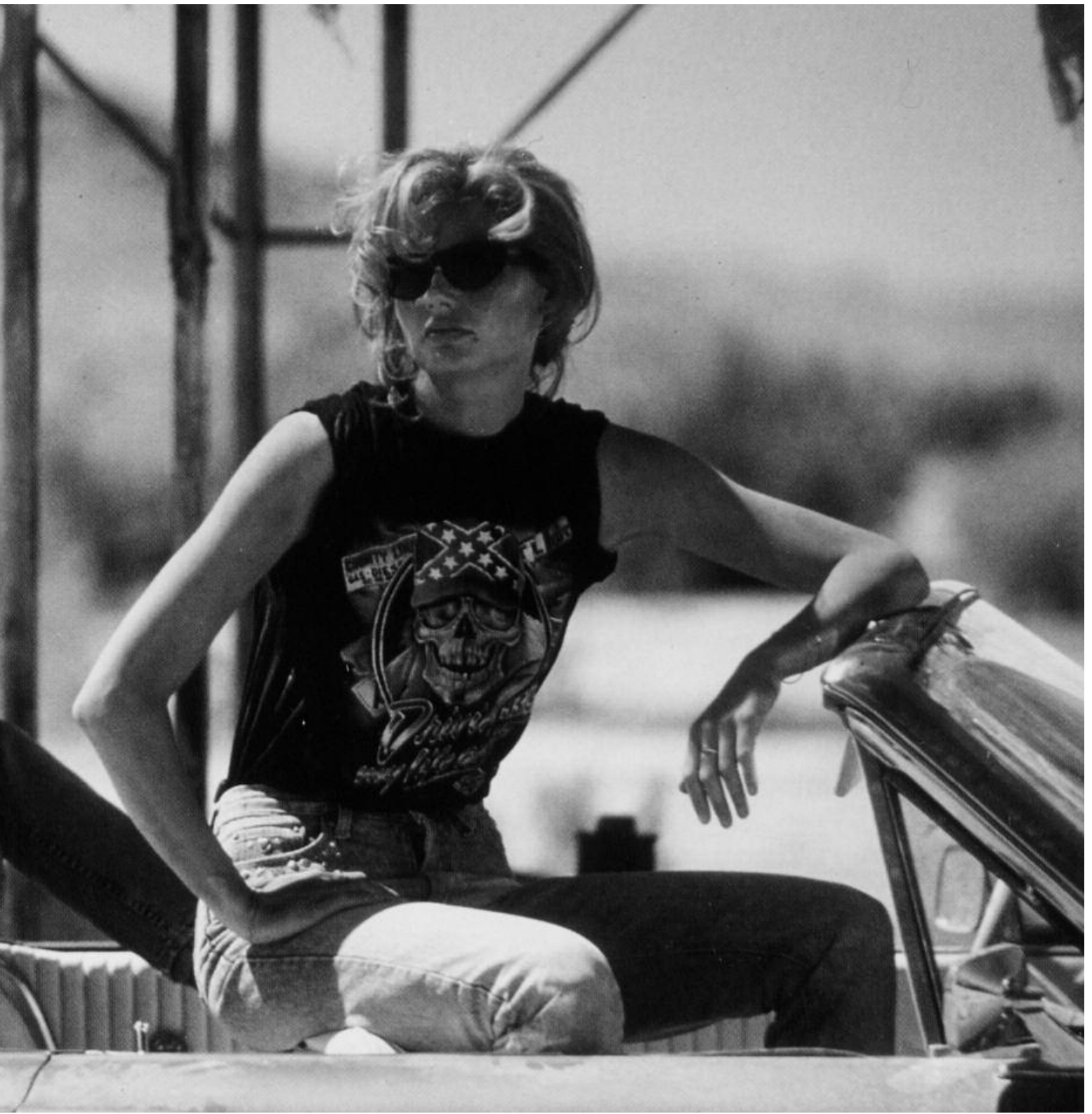

deling, idet han i 1990'erne har forsvaret sig mod den feministiske kritik ved at understrege, at den historisk-empiriske eksklusion af kvinder (fra den borgerlige offentlighed) ikke er det samme som en normativ eksklusion af kvinder fra selve offentlighedsmodellen og hermed hans diskursteoretiske demokratimodel (Habermas 1992).

\section{HABERMAS’ DEMOKRATITEORI}

Jeg vil i det følgende kort præsentere de centrale forestillinger, som den habermasianske demokratiteori er baseret på. En sådan præsentation kan præciseres ved at operere med en niveauopdeling, så det er muligt at tale om både en generel demokratiteori og et offentlighedsbegreb som en del af denne. I Fakticität und Geltung tager 
Habermas' demokratiteori afsæt i den deliberative demokratitradition ved at hente teoriens normative grundlag fra liberalisme og republikanisme. Sidstnævnte kan idéhistorisk identificeres som to normative forestillinger om henholdsvis folkets politiske deltagelse og selvbestemmelse (folkesuverænitet) og det enkelte individs frihedsrettigheder (den private og offentlige autonomi) (Eriksen 1995, Habermas 1992). Habermas' demokratimodel - det diskursteoretiske demokrati - medierer mellem disse traditioner. 6

Habermas abonnerer for det første på den republikanske forestilling om lige politisk deltagelse i fællesskabet uden dog at dele denne traditions vægt på frlles etiske værdier som normativt grundlag for politikken. Det er her, at forestillingen om inklusion har sin oprindelse. Fra den liberale tradition henter Habermas for det andet forestillingen om sikring af de individuelle friheds- og lighedsrettigheder gennem deltagelse i retsligt institutionaliserede lovgivningsprocesser. Offentlighedsmodellen er for det tredje baseret på ideen om politik som et resultat af en rationel og retfærdig procedure afgjort i det politiske fællesskab med universel gyldighed for alle individer. En konsekvens af denne procedurale demokratiopfattelse er, at politiske beslutninger kun er legitime, hvis de er taget på baggrund af offentlig deliberation (Habermas 1996, 274ff).

I hjertet af den habermasianske demokratiteori står offentlighedsbegrebet med dets vægt på kommunikation og debat. ${ }^{7}$ Dette er for det første baseret på idealet om lige politisk deltagelse for alle individer og for det andet på idéen om, at man som individ eller gruppe kun kan anerkendes qua denne deltagelse i offentligheden. På den ene side står de normative idealer, som er min genstand i denne artikel. På den anden side det empirisk-sociologiske begreb, hvor offentligheden kan betragtes som et fællesrum i samfundet, som er opsplittet i forskellige netværk som forsamlinger, fora, arenaer og scener, hvor borgere træffes som publikum. Offentligheden udgør på denne måde et komplekst netværk af deloffentligheder, som strækker sig over forskellige niveauer, rum og skalaer. I modsætning til den borgerlige offentlighed er offentlighedsbegrebet i Fakticität und Geltung ikke opdelt i en offentlig og en privat del. Denne grænsedragning er til stadig forhandling i moderne demokratier. Offentligheden spiller derfor en konstruktiv rolle $\mathrm{i}$ at få sager frem på den politiske dagsorden. Den sluser ligeledes nye problemstillinger ind $\mathrm{i}$ det parlamentariske system, idet den fungerer som sensor og antenne i forhold til disse (Eriksen 1994b, Habermas 1996, 359f).

Offentlighedsbegrebet har flere karakteristika. For det første at offentligheden er et rum for politisk argumentation, debat, deliberation og kommunikation, hvor politisk konsensus ikke forudsættes a priori. Deltagerne indgår i den offentlige debat og former via denne deltagelse en politisk mening. Det er i forlængelse heraf den franske politolog Bernard Manins pointe, at individer, der skal tage kollektive, politiske beslutninger, ikke a priori har bestemte præferencer og valg. Disse formuleres og præciseres i det argumenterende fællesskab, som offentligheden udgør (Manin 1987). Der er tre væsentlige kendetegn ved den deliberative proces. For det første akkumulerer den viden til deltagere. Ingen person kan forudse alle perspektiver på politiske og etiske spørgsmål eller kan rumme alle de informationer, som er relevant for en politisk beslutning. For det andet giver den individet mulighed for kritisk refleksion og argumentation og for at identificere sig med andres synspunkter og endeligt udgør den en proces, hvorigennem individers meninger tager form i det politiske fællesskab. Deliberationsprocessen tjener et grundlæggende formål i demokratiet: "The process of articulating good reason in public forces the individual to think of what would count as a good reason for all others involved" (Benhabib 1996, 71f, Manin 1987). 


\section{YOUNGS Habermas-KRITIK}

Iris Marion Young er filosof og arbejder med normativ politisk teori, feministisk teori, etik og offentlig politik. Hendes perspektiv tager afsæt i den erfaringsverden, hun selv har været en del af, nemlig de nye sociale bevægelser i USA. Dette afsæt fremhæver hun eksplicit som begrundelse for sit eksklusionsperspektiv på kvinder i politik. Hermed indskriver hun sig i hjertet af den amerikanske feministiske Habermas-diskussion med sin kritik rettet mod normative idealer i teorien, med sit afsæt i Frankfurterskolen og kritisk teori, sit perspektiv på politik og fokus på de grupper, som står overfor eksklusion fra demokratisk deltagelse (Young 1990, 1996). ${ }^{8}$ Youngs perspektiv på kvinders politiske deltagelse er dermed væsentligt forskelligt fra det top-down perspektiv, som er dominerende i nordisk forskning med særligt fokus på kvinder i parlamentarisk politik. Youngs to teoretiske begreber retfærdighed (enabling justice) og anerkendelse (recognition) er her centrale og kan i relation til Habermas anvendes til at diskutere både individuelle kvinders og grupper af kvinders rolle i den politiske offentlighed.

Youngs diskussion af retfærdighed er bredere, end det traditionelt har været tilfældet i politisk teori, hvor begrebet omhandler fordeling af materielle goder og ressourcer (Rawls 1971, Waltzer 1983). Ifølge Young er man med et sådant begreb i fare for at overse de sociale strukturer og institutionelle rammer, som ligeledes er bestemmende for en retfærdig fordeling i et samfund. Young udvider retfærdighedsbegrebet, så det både omfatter fordelingen af personers ejendom, indkomst og øvrige ressourcer og desuden ikke-fordelingsmæssige parametre som $\mathrm{fx}$ lige adgang til besluttende organer og procedurer. I relation til Habermas er den del af Youngs begreb, der omhandler beslutningsstrukturer et vigtigt omdrejningspunkt. I en habermasiansk forståelsesramme er et sådant retfærdighedsbegreb på linje med den normative fo- restilling om lige deltagelse for alle individer i det politiske fællesskab. Det centrale hos Young er, hvem der qua sin position og autoritet tager beslutninger og desuden, hvorledes regler og procedurer er formuleret for politisk beslutningstagning.

Youngs opfattelse af et retfærdigt, demokratisk samfund er derfor ikke kun et spørgsmål om lige fordeling af materielle goder, men rummer ligeledes et handlingsaspekt for alle samfundets medlemmer. Et sådant samfund tilbyder de institutionelle betingelser i demokratiet, som er nødvendige for at sikre lige politisk deltagelse og selvbestemmelse. Her indskriver Young sig i en empowerment-terminologi: retfærdighed er enabling. Et retfærdigt, demokratisk samfund gør individer i stand til at handle. Begrebets fokus er individer og gruppers handlingsrum i politik, hvilket er centralt i relation til Habermas' demokratiteori og dens accentuering af handling i offentligheden. Denne deltagelse kan enten have form af offentlige debatter i den store politiske offentlighed eller som deltagelse i mere specifikke deloffentligheder, der består af en afgrænset gruppe personer eller debatter omkring et afgrænset emne. Oversat til habermasiansk terminologi er denne handling derfor synonym med deltagelse i offentlighedens deliberationsprocesser. I min læsning af Young er et uretfærdigt, udemokratisk samfund karakteriseret ved en institutionel binding på både deltagelse i deliberationsprocesser og på selvbestemmelse over andre politiske handlinger, som individer $ø$ nsker at udføre. Young har blik for, at der de facto er grupper, som kan have vanskeligt ved at "komme til orde" og blive hørt i det diskursteoretiske demokrati og hermed vanskeligt ved at blive anerkendte som gruppe. Youngs brede retfærdighedsbegreb tolkes af Fraser som en dikotomi med både en politisk-økonomisk og en kulturel dimension (Fraser 1997). Hvor førstnævnte sætter retfærdighedsbegrebet i en kontekst af arbejdsdeling og udbytning, handler den kulturelle dimension af retfærdighed om 
kulturel anerkendelse og en gruppes mulighed for at udøve selvstændige, kulturelle udtryk. Det er sidstnævnte betydning, som er relevant i en diskussion af Habermas' anvendelse af Youngs begreber.

\section{Habermas og Youngs RETFÆRDIGHEDSBEGREB}

Young danner en frugtbar ramme for en feministisk diskussion af normative idealer $\mathrm{i}$ Habermas' demokratiteori, idet hendes retfærdighedsbegreb indgår som omdrejningspunkt for diskussionen af kvinder, kvindebevægelse og feminisme i sidste del af Fakticität und Geltung (Habermas 1996, afsnit 9.2.). Habermas laver her et interessant greb, idet han sammentænker republikanske forestillinger om politisk deltagelse og liberale forestillinger om privat og offentlig autonomi med kvinders politiske deltagelse i offentligheden. Habermas og Young tænker retfærdighed inden for samme begrebsverden, og Habermas anvender Youngs begreb som et eksempel på denne sondring. Habermas sondrer mellem forskellige typer af retfærdighed: en retfærdig fordeling af velfærd (well-being) og en retfærdig fordeling af personlig, politisk handlefrihed og selvbestemmelse (privat og offentlig autonomi). Det er her en pointe, at velfærdssystemer, der reducerer rettigheder til et spørgsmål om lige fordeling af materielle sociale goder, overser det frihedsgaranterende element, som den individuelle handlefrihed udgør. Den amerikanske sociolog T.S. Marshall kan anvendes til at belyse Habermas' position. Marshall skelner mellem civile (privat autonomi), politiske (offentlig autonomi) og sociale rettigheder (Marshall 1950). Et velfærdsstatsligt paradigme priviligerer sociale rettigheder, mens Habermas priviligerer de politiske. Han argumenterer for, at civile, private og politiske rettigheder er grundlag for demokrati, mens sociale rettigheder kun er sekundære. Dette afspejles i den diskursteoretiske demokratimodels vægt på deltagelse og anerkendelse som kernen i den politiske offentlighed og som nøglen til et retfærdigt samfund: "The idea of a just society is connected with the promise of emancipation and human dignity" (Habermas 1996, 418).

Habermas anvender Youngs retfærdighedsbegreb til at illustrere sin vægtning af de politiske rettigheder, som gør individet $\mathrm{i}$ stand til at handle: "Rights refer to doing more than having, to social relationships that enable or constrain action" (Habermas $1996,418 \mathrm{ff}$, Young 1990). Som citatet viser, er retfærdighed og en retfærdig behandling af kvinder i demokratiet ikke udelukkende et velfærdsspørgsmål. Rettigheder må forstås som tostrengede: både som en velfærdsgaranti og som en mulighed for at tildele kvinder handlefrihed til at forme deres egne liv. Mere konkret vil dette sige politisk deltagelse for kvinder. Hvis modellen ikke rummer en sådan dobbelthed, ekskluderes kvinder af politik. Hermed er samfundet ikke retfærdigt og demokratiet uden virke:

"Rights can empower women to shape their own lives autonomously only to the extent that these rights also facilitate equal participation in the practice of civic self-determination because only women themselves can clarify the "relevant aspects" that define equality and inequality for a given matter" (Habermas $1996,420)$.

\section{ANERKENDELSE AF KVINDER I OFFENTLIGHEDEN}

Youngs begreb om anerkendelse (recognition) er altså todelt med en politisk-økonomisk og en kulturel dimension (Fraser 1995, Young 1990). Hos Habermas er det netop den sidstnævnte, som diskuteres i relation til kvinder og kvindebevægelsen. Habermas lægger vægt på lige deltagelse i offentligheden for alle medlemmer af det demokratiske fællesskab. Det er ifølge teorien kun qua de facto deltagelse, at kvinder kan anerkendes i politik og udforme deres eget 
"gode (kvinde)liv". Denne forestilling tolkes af feministiske kritikere som en håndsrækning frem mod kvindebevægelsen og feminismen, idet det brede begreb om handlefrihed knyttes direkte til feminismens historie (Warnke 2000). Dette belyser det perspektivskifte på køn, som Habermas' teorikonstruktion har gennemgået fra 1980'ernes kønsblindhed til 1990'ernes inddragelse af og reference til feminisme, kvinder og kvindekønsforskning (Habermas 1984, 1996).

Kvinders mulighed for at virkeliggøre egne behov og opnå anerkendelse afhænger i Habermas' demokrati- og offentlighedsmodel af udviklingen af relationer om gensidig anerkendelse. Disse forhold omfatter både tætte relationer af kærlighed og venskab og juridiske relationer af universel respekt for autonomi og desuden af netværk for solidaritet og fælles værdier. Sådanne forhold etableres og udvides gennem sociale kampe $a$ struggle for recognition (Honneth 1995). Habermas formulerer selv dette således:

"The classification of gender roles and gender-related differences touches elementary layers of a society's cultural self-understanding .... Competing views about the identity of the sexes and their relation to each other must be open to public discussion. Even the feminist avant-garde does not have a monopoly on definition" (Habermas 1996, 425f).

Kvinders deltagelse i offentligheden og hermed i politik er afgørende for, om anerkendelse, identitet, køn og kønsroller vil indgå i den offentlige debat. Ligesom anerkendelse af kvinders politiske rettigheder og kulturelle status i samfundet afhænger af en de facto anerkendelse af kvinder som zoon politicon. Brede sociale grupper af kvinder. Med et sådant perspektiv på kvinders deltagelse træder det normative ideal om deliberation i karakter. Deliberation i offentligheden forudsætter ikke fastlagte definitioner af kvinders behov, identiteter eller meninger, men skaber rum for en fri debat af em- ner som behovsfortolkninger, kønsforskelle og opfattelser af lighed. Ved at understrege dette trækker Habermas i retning af den slags diskurser, som han kalder "etisk-politiske" diskurser omkring spørgsmål som hvem er jeg og hvem vil jeg gerne vare? (Warnke 2000).

I en empirisk parentes kan man ligeledes læse Habermas' åbenhed mod kvinder og kvindebevægelsen som en erkendelse af, at den meningsdannende offentlighed har haft betydning for politisk beslutningstagning i kraft af en række udenomsparlamentariske aktioner.9 I et historisk perspektiv er kvindebevægelsen netop et eksempel på en gruppe, hvis aktioner har ledt til en mentalitetsforandring og har bragt nye politiske problemstillinger og sagskomplekser på den politiske dagsorden. Dette kan ikke forklares ved aktørens egeninteresse eller magtgruppers strategier, men derimod af problemstillingernes almene karakter (Eriksen og Weigård 1999, Loftager 1994).

\section{SPØRGSMÅL TIL NORDISK FORSKNING OM KVINDER I POLITIK}

Trods forskelle mellem den amerikanske feministiske Habermas-kritik og nordisk forskning kan Young i mine øjne give et frugtbart bidrag og udfordre nordiske forskning om kvinder i politik. Hendes to begreber retfærdighed (enabling justice) og anerkendelse (recognition) er centrale som afsæt for en feministisk læsning af Habermas, fordi de med udgangspunkt i et eksklusionsperspektiv åbner for en teoretisk diskussion af barrierer og muligheder for kvinders politiske deltagelse. Youngs styrke er, at hun kombinerer et eksklusions- og et inklusionsperspektiv i form af sit begreb om politisk-økonomisk og kulturel anerkendelse. Ved at understrege at anerkendelse kræver begge dimensioner giver hun et godt afsæt for at diskutere det dominerende (inklusions)perspektiv på kvinders politiske deltagelse i Norden. Anerkendelse af gruppers behov, interesser og repræsenta- 
tion i beslutningsfora af forskellig art og i den politiske offentlighed.

Man kan tale om et perspektivskifte indenfor den empiriske, skandinaviske kvinde-kønsforskning. I begyndelsen af 1980’erne fokuserede forskningen på kvinders politiske marginalisering og eksklusion med det resultat, at kvinders deltagelse i det offentlige liv blev beskrevet som en overgang fra afmagt uden deltagelse til relativ afmagt trods deltagelse (Haavio-Mannila 1983). Dette perspektiv er gradvist blevet afløst af en mere optimistisk tilgang med fokus på kvinders aktive medborgerskab i de nordiske velfærdsstater. Disse karakteriseres som "kvindevenlige", hvor staten gennem udbygning af socialpolitik har sikret kvinder økonomisk uafhængighed. Desuden fokuseres på politisk integration og inklusion. Fokus er hermed på kvinders aktive medborgerskab, som omfatter kvinders tilstedeværelse på alle politiske arenaer og niveauer i det politiske liv (Hernes 1987, Raum 1995, Siim 1988, 1999, Skjeie 1992, Togeby 1995 ).

Som jeg læser Youngs begreber og Habermas' læsning af hende, kan hun anvendes til at belyse, at der kan være problemer i udelukkende at anskue kvinders politiske deltagelse i et inklusionsperspektiv. Særligt hvis man flytter fokus fra det individuelle til det kollektive niveau. Forskellige grupper af kvinder har ulige betingelser for politisk deltagelse, og det er ikke alle grupper, som betragtes som politiske deltagere i det nordiske, politiske landskab. Denne manglende anerkendelse kan både tage form af deltagelse i politisk organisering eller i den offentlige debat. Minoritetsgrupper af bestemte etniske mindretal eller den nyfeministiske bølge i Skandinavien er eksempler på grupper, der kan have vanskeligt ved at blive anerkendt. Det synes som om, at denne problematik rummer flere facetter: dels anerkendelsen af gruppers behov, interesser og representation, dels en de facto anerkendelse af gruppers konstituering som gruppe og endeligt en mere specifik anerkendelse af afgrænsede deloffentligheder eller særlige debatter i den politiske offentlighed. 10

Den nyfeministiske bølge har rullet over Skandinavien siden 1998 med bogudgivelser i Norge, Sverige og Danmark. Disse bøger har været fulgt af en intensiv mediedebat og interesse, men har ligeledes været underlagt en voldsom kritik. Den danske udgave Fisseflokken er blevet kritiseret for udelukkende at genfortælle 18 individuelle, navlebeskuende beretninger uden generaliseringsværdi og uden politisk udblik, kritik eller visioner (Skugge 1999). ${ }^{11}$ I lyset af Youngs begreb om kulturel anerkendelse og Habermas' anvendelse af dette begreb som illustration af sit offentlighedsbegrebs funktionsdygtighed må man spørge, om ikke en ung generations bud på en feminisme - nyfeminisme - lider under en manglende anerkendelse. Hvis den debat, som foregår i en nyfeministisk deloffentlighed - deliberationsprocessen - betragtes som individuelle beretninger uden deliberationens kollektive og meningsflyttende karakter, kan man vel næppe tale om en anerkendt debat.

Dette rejser mere generelt spørgsmålet om, hvem der har autoritet til at tale og på vegne af hvem, og hvem der anerkendes som "samtalepartnere", og hvem der ikke gør. Som jeg betragter disse spørgsmål, må udfordringen til demokratiet være at få forskellige deloffentligheder til at tale sammen. Herved kan man opnå en gensidig anerkendelse af hinanden som selvstændige subjekter, og uden en sådan anerkendelse opnås ingen dialog.

\section{OpSUMMERING}

Idealerne om inklusion og deltagelse udgør to af de bærende normative idéer i Habermas' demokratimodel; det diskursteoretiske demokrati, som det er formuleret i hans 1990'er hovedværk Fakticitüt und Geltung. Disse idealer indgår som vigtige omdrejningspunkter i den amerikanske, feministiske Habermas-kritik, som er opstået i slutningen af 1980'erne blandt feministiske po- 
litologer, sociologer og filosoffer. Den amerikanske filosof Iris Marion Youngs to begreber retfærdighed (enabling justice) og anerkendelse (recognition) er frugtbare og finder anvendelse i Habermas' (demokrati)teori som illustration af spørgsmålet om kvinders politiske deltagelse og særligt deltagelse i den politiske offentlighed. Med en spidsformulering kan man sige, at modellens normative deltagelsesideal ikke kan realiseres uden alle gruppers og herunder kvinders deltagelse. Youngs dobbeltsidede anerkendelsesbegreb med både en politiskøkonomisk og en kulturel dimension anvendes i Habermas' model til at diskutere anerkendelse af kvinder, kvindebevægelse og feminisme. Det er Youngs pointe, at kvinder er ekskluderede af politik. Hendes anerkendelsesbegreb giver for det første et teoretisk grundlag at diskutere eksklusion på baggrund af og desuden en mulighed for at kombinere et eksklusions- og et inklusionsperspektiv på kvinders politiske deltagelse. Dette er frugtbart i relation til Habermas' demokratimodel og til nordisk forskning om kvinder i politik.

\section{NoTER}

1. Jeg vil i det følgende anvende de engelske oversættelser af Habermas' værker som reference.

2. Se bl.a. Bussemaker og Voet 1998, Siim 1998.

3 . Frankfurterskolen blev grundlagt omkring miljøet ved Institut für Sozialforschung i Frankfurt omkring $1930 \mathrm{og}$ forskere som Horkheimer, Adorno, Marcuse. Instituttet flyttede til USA under 2. verdenskrig, men vendte tilbage til Frankfurt i efterkrigstiden.

4. Se desuden Hernes 1987, Raum 1995, Siim 1988, 1999, Skjeie 1992, Togeby 1995, Wängnerud 1998.

5. For en analyse af Habermas' standardværk Borgerlige Offentlighed se Eriksen og Weigård 1999.

Se også Calhoun (ed.), 1992, Meeham (ed.) 1995, White 1988.

6. Begrebet deliberativt demokrati indgår som et "modeord" i den politiske terminologi. Begrebet er relativt nyt og kan spores tilbage til artiklen "Deliberative Democracy: The Majority Principle in Republican Government" af J. M. Bessette (1980). Baggrunden for begrebet er John Dewey og hans bog The Public and its Problems (1927). Se desuden Eriksen og Weigård for en række litteraturreferencer $(1999,152)$. Jf. Benhabib (eds. 1996, 6) anvender Habermas termerne diskursteoretisk demokrati og deliberativ politikmodel synonymt. Jeg vil i det følgende anvende førstnævinte som udtryk for Habermas' deliberative demokratimodel. Liberalisme og republikanisme kan idéhistorisk identificeres som to normative forestillinger om hhv. folkesuverænitet (vægt på deltagelse) og menneskerettigheder (vægt på frihedsrettigheder). 7. Weber kategoriserer fire handlingstyper og aktører, som udfører disse. Den første kategori er den formålsrationelle handling, hvor aktøren rationelt og resultatorienteret arbejder mod bestemte mål. Hun tager ligeledes hensyn til følgerne af fravalg. Den værdirationelle handling tager afsæt i en bevidst tro på egenværdien af en bestemt adfærd. Den tredje type er den affektive handling, som er styret af aktørens følelser. Her har man ikke kontrol over de værdier, som ligger til grund for ens handling, men til trods for dette vælger aktøren selv mål og midler. Den fjerde type er den traditionelle handling, som er styret af vanetænkning. Her har aktøren kontrol over midler, men ikke over de værdier og mål, som ligger bag. Fra den formålsrationelle til den traditionelle handlingstype sker der en gradvis opgivelse af aktørens rationelle kontrol over en handling. Hermed er det den formålsrationelle handlingstype, som udgør Webers rationelle ideal og hermed er målestok for resten af typologien (Eriksen og Weigård 1999). På baggrund af Webers typologi stiller Habermas spørgsmålet om den formålsrationelle handlingstype kan give et udtømmende billede af socialt samspil og kommunikation mellem aktører. Det er hans pointe, at denne ikke er tilstrækkelig til at beskrive samfundet handlingsteoretisk. I forlængelse af denne erkendelse indfører Habermas sine normative idealtyper: de kommunikative handlinger og den kommunikative rationalitet til at beskrive interaktion mellem individer, som er forståelsesorienterede og ikke formålsorienterede. Herved skubbes forfølgelsen af individuelle mål for den enkelte i baggrunden til fordel for en fælles forståelse med andre aktører om, hvorledes der bør handles i en given situation. 8. Det følgende afsnit er baseret på disse værker af Young.

9. I den nye offentlighedsmodel sondrer Habermas mellem svage og stærke offentligheder. Denne sondring henter han fra den amerikanske feminist Nancy Fraser. Til den stærke offentlighed henhører parlamentariske forsamlinger og diskursive organer i formelle organisationer, hvor der foregår afstemninger. Svage offentligheder omfatter den debat, 
som udspringer af civilsamfundets sociale bevægelser uden for det politiske system. Meningsdannelsesprocesser er knyttet til denne type af offentlighed. Det er netop de svage offentligheder, som er " the vehicle of public opinion" (Fraser 1992, $\mathrm{Ha}^{-}$ bermas 1996, 307). Fraser anvender ligeledes begrebet "subaltern counterpublics" til at beskrive en kategori af offentlighed. Eriksen og Weigård kritiserer Habermas' sondring mellem de to offentlighedsformer for at mangle sammenhæng (1999, kap.9).

10. Se Birte Siims artikel i dette tidsskrift for en diskussion af Youngs gruppebegreb.

11. Jeg har andetsteds argumenteret for, at en sådan tolkning peger i retning af, at anmelderen adapterer et snævert politikbegreb, hvor politik er knyttet op på den parlamentariske styringskæde og herved dannes i Folketing, ministerier, den korporative kanal ol. Fisseflokken abonnerer på et bredere politkbegreb, som udspringer af det senmoderne samfunds insistering på sammenhæng mellem hverdagsliv og politik (Fiig 2000).

\section{LITTERATUR}

- Benhabib, S. (1986a): Critique, Norm, and Utopia, A Study of the Foundations of Critical Theory, Columbia University Press, New York

- Benhabib, S. (1992): Situating the Self. Gender, Community and Postmodernism in Contemporary Ethics, Polity Press, Cambridge

- Benhabib, S. (ed.) (1996): Democracy and Difference. Contesting the Boundaries of the Political, Princeton University Press, Princeton

- Benhabib, S. \& D. Cornell (eds.) (1986): Feminism as Critique, Polity Press, Cambridge

- Bergqvist, C. (1995): “The Declining corporatist state and the political gender dimension" in Karvonen og Selle (eds.): Closing the Gap. Women in Nordic Politics, Aldershot, Dartmouth - Bussemaker, J. og R. Voet (1998): “Citizenship and Gender: theoretical approaches and historical legacies" in Critical Social Policy, vol 18 (3), August, issue 56

- Calhoun, C. (ed.) (1992): Habermas and the public Sphere; MIT Press, Cambridge, Massachusetts

. Cohen, J. ( 1996): "Democray, Difference and the Right of Privacy" in Benhabib(ed.): Democracy and Difference. Contesting the Boundaries of the Political, Princeton University Press, Princeton - Dahlerup, D.: "From a Small to a Large Minority. Women in Scandinavian Politics" in Scandinavian Political Studies, årg. 11, nr. 4, pp.275-98
. Eriksen, E. O. (ed.) (1994): Den politiske orden, TANO, Oslo

- Eriksen, E. O. (ed.) (1995): Deliberativ politikk.

Demokrati i teori og praksis, TANO, Oslo

- Eriksen, E.O. og Weigaard, J. (1999): Kommunikativ handling og deliberativt demokrati. Jürgen Habermas' teori om politikk og samfunn, Fagbokforlaget, Oslo

- Fiig,C. (1997): Den Konkrete Anden / Feministisk kritik af Habermas offentlighedsbegreb med fokus på Seyla Benhabibs bidrag, Institut for Statskundskab, Aarhus

- Fiig,C. (2000): "Nyfeministisk kioskbasker. Anmeldelse af "Fisseflokken" in Kontur Tidsskrift for Kulturstudier 1 . årgang, 2000

. Flemming, M. (1995): "Women and the Public Use of Reason" in Meehan, J.: Feminists read Habermas: Gendering the Subject of Discourse, Routledge, New York

- Fraser, N. (1986): "What's Critical about Critical Theory?" in Benhabib, S. \& D. Cornell (eds) Feminism as Critique, Polity Press, Cambridge - Fraser, N. (1989): Unruly Practices: Power, Discourse and Gender in Contemporary Social Theory, Polity Press, UK

- Fraser, N. (1992): "Rethinkning the Public Sphere: A Contribution to the Critique of Actually Existing Democracy" in Calhuon, C.(ed.): Habermas and the public Sphere; MIT Press, Cambridge, Massachusetts

. Fraser, N. (1995): “Debate: Recognition or Redistribution? A Critical Reading of Iris Young's Justice and the Politics of Difference" in The Journal of Political Philosophy, vol. 3, nr.2, 1995

- Haavio- Mannila, E. et al. (1983): Det Uferdige Demokrati. Kvinner i nordisk politikk, Nordisk Ministerråd

- Honneth, A. (1995): The Struggle for Recognition. The Moral Grammar of Social Conflicts, Polity Press,

- Gould, C.C. (1996): "Diversity and Democracy: Representing Differences" in Benhabib (ed.): Democracy and Difference. Contesting the Boundaries of the Political, Princeton University Press, Princeton, Massachusetts

- Habermas, J. (1974, original 1962): Borgerlig offentlighet - dens framvekst og forfall, Fremad, København

- Habermas, J. (1984/1987): The Theory of Communicative Action, vol. 1 og 2, Beacon Press, 1984 (vol.1) og 1987 (vol.2), (Orig. 1981) - Habermas, J. (1992): "Further Reflections on the Public Sphere" in Calhoun, C. (ed.) (1992): Habermas and the public Sphere, MIT Press, Cambridge 
- Habermas, J. (1996, original 1992): Between Facts and Norms. Contributions to a Discourse Theory of Law and Democracy, MIT Press, Cambridge, Massachusetts

- Hernes, H.M. (1987): Welfare state and Woman power: Essays in State Feminism, Universitetsforlaget, Oslo

- Jonasdottir, A.G.og Jones, K.B (eds.) (1988):

The Political Interest of Gender/Developing Theory and Research with a Feminist Face, Sage, London - Karvonen. L. og Selle, P. (eds.) (1995): Closing the Gap. Women in Nordic Politics, Aldershot, Dartmouth,

- Loftager, J. (1994): "Den politiske offentlighed i teori og i praksis" in Eriksen (ed.) Den politiske orden, TANO, Oslo

- Landes, J.B. (1988): Women and the Public Sphere in the Age of the French Revolution, Cornell University Press, New York,

- Manin, B. (1987): “On Legitimacy and Political

Deliberation. A Sketch of a Theory of Political

Deliberation" in Political Theory, vol. 15, no.3,

August 1987

- Marshall, T.H. (1950): Citizenship and Social Class, Cambridge University Press, Cambridge

- Meehan, J. (1995): Feminists read Habermas:

Gendering the Subject of Discourse, Routledge,

New York

- Nørager, T. (1985): System og livsverden. Jurgen

Habermas' konstruktion af det moderne, Anis, Frederiksberg

- Phillips, A. (1995): The Politics of Presence, Polity Press, London

- Raum, N.C. (1995): "Women in local Democracy" in Karvonen og Selle (eds.): Closing the Gap.

Women in Nordic Politics Aldershot, Dartmouth

- Rawls, J. (1972): A Theory of Justice, Oxford

University Press, Oxford

- Schudson, M. (1992): "Was There Ever a Public Sphere?" in Calhoun (ed.): Habermas and the Public Sphere; MIT Press, Cambridge, Massachusetts - Siim, B. (1988): “Towards a Feminist Rethinking of the Welfare State", in Jonasdottir,A.G. og Jones K.B. (eds.), The Political Interest of Gender/Developing Theory and Research with a Feminist Face,

Sage, London

- Siim, B. (1999): "Feministiske perspektiver på demokrati og medborgerskab" in Aronsson et al. (1999): Demokrati og medborgerskab, Demokratiutredningens forskervolymII, SOU: 77, Sweden - Skjeie, H. (1992): Den politiske betydning af kjønn, Institute for Social Research, Oslo University, rapport 92:11, Oslo
- Skugge, L. N. et al. (1999) (dansk red. Grøntved C.): Fisseflokken, Informations Forlag, København - Togeby, L. (1994): Fra Tilskuer til deltager. Den kollektive politiske mobilisering af kvinder $i$ Danmark i 1970'erne og 1980'erne, Politica, Institut for Statskundskab, Aarhus Universitet

- Togeby, L. (1995): "A Gender Gap that vanished" in Karvonen og Selle (eds.): Closing the Gap. Women in Nordic Politics, Aldershot, Dartmouth, . Young, I.M. (1990): Justice and the Politics of Difference, Princeton University Press, 1990

- Young, I.M. (1996): "Communication and the Other": Beyond Deliberative Democracy", in Benhabib (ed.): Democracy and Difference. Contesting the Boundaries of the Political, Princeton University Press, Princeton

· Wängnerud, L. (1998): Politikens Andre Sida. Om Kvinnorrepresentation i Sveriges Riksdag, Göteborg Studies in Politics 53, Göteborg . Warnke, G. (2000): "Feminism and democratic deliberation" in Philosophy \& Social Criticism, vol. 26, nr.3, May

- Walzer, M. (1983): Spheres of Justice, Basic, New York

- Weber, M. (1922/ 1978): Economy and Society, vol. I og II, , California, University of California Press, Berkeley

- Østerud, S. (1996): "Forandringer i den politiske kommunikation”, Grus nr. 49

\section{SUMMARY}

The purpose of this article is to present the American feminist Habermas-critique. The critique is multi-disciplinary and discusses various aspects of the Habermasian theory of democracy. The author reads Youngs' concept of recognition which has got two dimensions: a political-economical and a cultural. The concept is used as a way of discussing women, the women's movement and feminism in $\mathrm{Ha}$ bermas. The author argues that this concept is useful to an understanding of Habermas and as a perspective in Nordic research on women in politics.

Christina Fiig, cand.scient.pol.

Ph.d. stipendiat ved FREIA, Institut for

Samfundsudvikling og Planlægning.

Aalborg Universitet 